X-ray Structure A nalysis 0 nline

\title{
Crystal Structure of a-Phenyl-N-thioacetylmorpholine
}

\author{
İ. Çelík, ${ }^{* 1}$ M. AKKurT*2, İ. DemirtaŞ, ${ }^{* 3}$ R. ERENLER, ${ }^{* 3}$ and K. GüVEN*4 \\ *1 Department of Physics, Faculty of Arts and Sciences, Cumhuriyet University, 58140 Sivas, Turkey \\ *2 Department of Physics, Faculty of Arts and Sciences, Erciyes University, 38039 Kayseri, Turkey \\ *3 Department of Chemistry, Faculty of Arts and Sciences, Gaziosmanpasa University, 60240 Tokat, Turkey \\ *4 Department of Physics, Faculty of Arts and Sciences, Kirlkkale University, \\ Yahşihan, 71450 Kırıkkale, Turkey
}

\begin{abstract}
The title compound, $\mathrm{C}_{12} \mathrm{H}_{15} \mathrm{NOS}$, consists of a thioamid and an $\alpha$-substituted phenyl group. It crystallizes in the monoclinic space group $P 2_{1} / c$. The unit-cell parameters at $293 \mathrm{~K}$ are $a=6.553(5), b=23.362(5), c=8.201(5) \AA$, $\beta=$ $112.532(5)^{\circ}, V=1159.7(12) \AA^{3}, D_{\mathrm{x}}=1.268 \mathrm{~g} / \mathrm{cm}^{3}, Z=4$. The morpholine group takes a chair conformation.
\end{abstract}

(Received February 23, 2004; Accepted May 14, 2004; Published on Web July 12, 2004)

Thioamides are versatile compounds that have found wide applications in the synthesis of industrial and fine chemical products. $^{1} \quad$ They are used as vulcanization accelerators, additives to lubricating oils, corrosion inhibitors, flotation agents, insecticides and fungicides, preservatives, and intermediates for preparation of certain vitamins $\left(\right.$ e.g. $\left.\mathrm{B}_{1}\right)$ and other pharmaceutical products. ${ }^{2}$ Thioamides have also attracted attention in peptide chemistry. ${ }^{3}$ Particularly, $\alpha$-substituted thioacetylamides are useful synthetic intermediates and would provide an alternative route to aryl propionic acids used in the synthesis of non-steroidal anti-inflammatory and analgesic drugs. Aryl and aryl alkyl thioamides and their corresponding carboxylic acids are useful organic compounds and are used as biologically active compounds such as pesticides ${ }^{4}$ or antiulcer agents. $^{5}$

We therefore carried out the Willgerodt-Kindler reaction of acetofenon with sulfur and morpholine in reflux temperature. In this study, the crystal structure of the title compound was determined by $\mathrm{X}$-ray analysis.

A mixture of ketone $(1.5 \mathrm{~g}, 12.5 \mathrm{mmol})$, sulfur $(0.5 \mathrm{~g}, 15.6$ mmol), and morpholine $(1.22 \mathrm{~g}, 14 \mathrm{mmol}, 1.22 \mathrm{ml})$ in a Pyrex glass was refluxed for $5 \mathrm{~h}$. The reaction was monitored with TLC. After cooling, the reaction product $\mathbf{4}$ was purified with silica gel chromatography by eluting with hexane-ethyl acetate (8:2) to give a colorless solid (2 g, $72 \%)$. M.p. $352-353 \mathrm{~K}$. Analysis calculated for $\mathrm{C}_{12} \mathrm{H}_{15} \mathrm{NOS}$ : C 65.19, H 6.79, N $6.32 \%$; found: C 65.10, H 6.85, N 6.35\%.

A summary of the crystallographic information is given in Table 1. The data were collected on a Rigaku AFC-7S diffractometer using graphite-monochromated Mo $K_{\alpha}$ radiation with the $\omega / 2 \theta$ scan mode. The collected data were reduced by

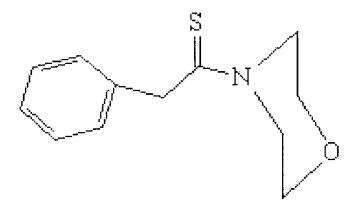

Fig. 1 Chemical diagram of the analyzed compound. using the MSC/AFC Diffractometer Control Software and empirical absorption correction was carried out by using the TEXSAN program. ${ }^{6}$ The title compound was solved by direct methods and refined by full-matrix least-squares method on $F^{2}$. All $\mathrm{H}$ atoms were located geometrically, at distances of $0.93(\mathrm{CH})$ and $0.97\left(\mathrm{CH}_{2}\right)$ from the parent atoms. They were refined by using a riding model and the $U_{\text {iso }}$ values were constrained to be 1.2 times $U_{\text {eq }}$ of the parent atom. The final conventional $R(F)=0.0450$ and $w R\left(F^{2}\right)=0.1263$ or $I \geq 2 \sigma(I)$ with weighting scheme, $w=1 /\left[\sigma^{2}\left(F_{\mathrm{o}}^{2}\right)+(0.0868 P)^{2}+0.3367 P\right]$. The atomic coordinates and equivalent isotropic displacement parameters with estimated standard deviations for the other atoms except $\mathrm{H}$ are listed in Table 2. An ORTEP drawing of the title compound with atom numbering is shown in Fig. 2. X-ray results for geometrical parameters are given in Table 3 .

The structure analysis of the title compound has revealed that the morpholine group takes a chair conformation with high stability [Puckering parameters: $Q=0.5483 \AA, \theta=1.72^{\circ}$ and $\varphi$

Table 1 Crystal and experimental data

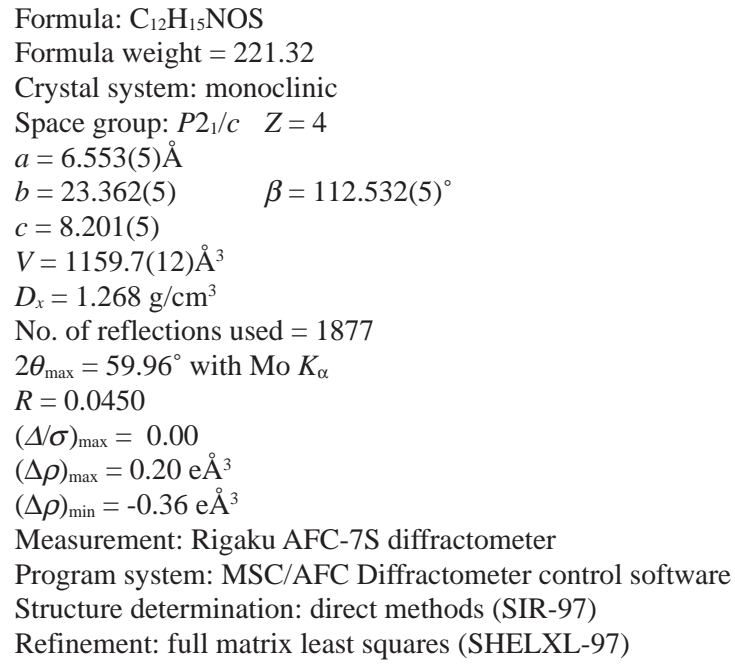




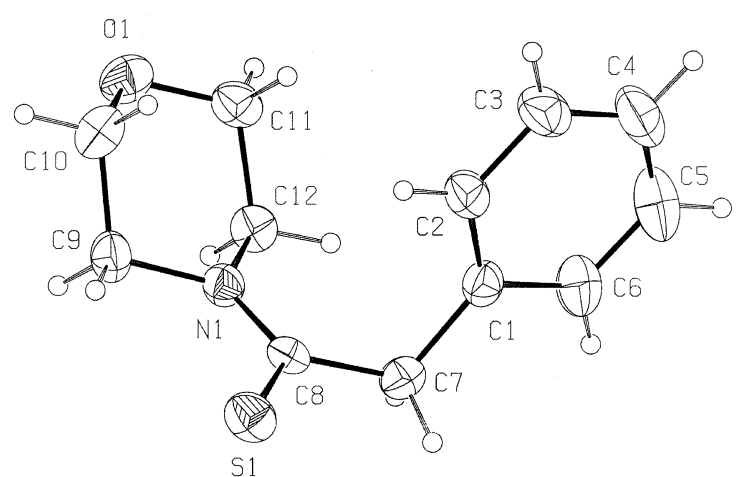

Fig. 2 An ORTEPORTEP view of the title molecule, showing $30 \%$ probability displacement ellipsoids and the atom-numbering scheme.

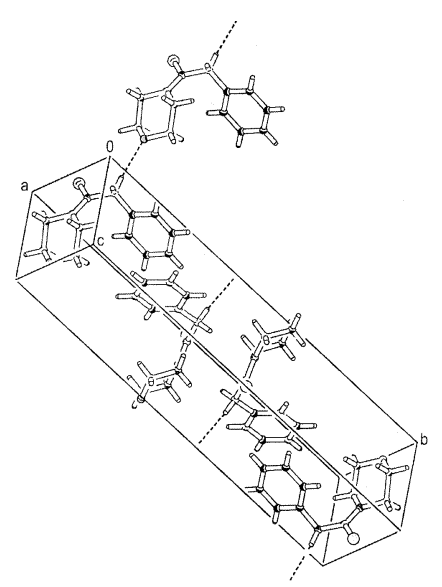

Fig. 3 A view of ORTEP the packing and the hydrogen contacts of the title molecule.

$\left.=1.2159^{\circ}\right]^{7}$ The bond lengths and angles of the title compound are in good agreement with thosein the literature. The six atoms of $\mathrm{S} 1, \mathrm{~N} 1, \mathrm{C} 7, \mathrm{C} 8, \mathrm{C} 9$ and $\mathrm{C} 12$ form a plane with the maximum deviations of $0.008(3) \AA$ for the $\mathrm{C} 12$ atom and of $-0.008(3) \AA$ for the $\mathrm{C} 7$ atom.

There are one $\mathrm{C}-\mathrm{H} \cdots \mathrm{O}$ type-intermolecular contact and one $\mathrm{C}-\mathrm{H} \cdot \mathrm{*} \mathrm{S}$ type-intramolecular hydrogen contact in the crystal structure of the title compound (Fig. 3 and Table 4). The crystal is not packed only by the inter-molecular hydrogen contact but also by non-parallel stacking of phenyl rings, as can be seen from Fig. 3. The angle between $\mathrm{H} \cdots \mathrm{S}-\mathrm{C}$ is almost perpendicular; the very short $\mathrm{C}-\mathrm{H} \cdots \mathrm{S}$ contact might be connected with the conjugation between $\mathrm{S}=\mathrm{C}$ bond and $\mathrm{N}$ atom.

\section{References}

1. P. Marchand, M. C. Fargeer-Bellasoued, and C. Bellec, Synthesis, 1994, 11, 1118.
Table 2 Atomic coordinates and temperature factors

\begin{tabular}{clccl}
\hline Atom & \multicolumn{1}{c}{$x$} & $y$ & $z$ & $U_{(\mathrm{eq})}\left[\AA^{2}\right]$ \\
\hline S1 & $0.67469(14)$ & $0.06145(3)$ & $-0.16094(12)$ & $0.0628(3)$ \\
01 & $1.0104(4)$ & $0.08766(1))$ & $0.5141(3)$ & $0.0659(7)$ \\
N1 & $0.6995(3)$ & $0.06459(9)$ & $0.1679(3)$ & $0.0468(6)$ \\
C1 & $0.3483(4)$ & $0.16227(11)$ & $-0.0055(4)$ & $0.0501(7)$ \\
C2 & $0.5300(5)$ & $0.19829(11)$ & $0.0405(5)$ & $0.0603(9)$ \\
C3 & $0.5151(7)$ & $0.25481(13)$ & $0.0823(6)$ & $0.0758(13)$ \\
C4 & $0.3185(8)$ & $0.27642(1)$ & $0.0773(7)$ & $0.0922(15)$ \\
C5 & $0.1377(7)$ & $0.2412(2)$ & $0.0319(8)$ & $0.106(2)$ \\
C6 & $0.1520(5)$ & $0.18491(16)$ & $-0.0068(6)$ & $0.0766(13)$ \\
C7 & $0.3530(4)$ & $0.10048(11)$ & $-0.0554(4)$ & $0.0527(8)$ \\
C8 & $0.5830(4)$ & $0.07522(9)$ & $-0.0050(4)$ & $0.0428(7)$ \\
C9 & $0.9235(4)$ & $0.03969(12)$ & $0.2345(4)$ & $0.0575(9)$ \\
C10 & $1.0805(5)$ & $0.07808(15)$ & $0.3770(5)$ & $0.0666(10)$ \\
C11 & $0.7963(5)$ & $0.11344(13)$ & $0.4486(4)$ & $0.0593(9)$ \\
C12 & $0.6269(4)$ & $0.07643(12)$ & $0.3083(4)$ & $0.0526(9)$ \\
\hline
\end{tabular}

$U_{\text {(eq) }}=1 / 3$ of the trace of the orthogonalized $U$ tensor

Table 3 Selected bond distances $(\AA)$ and angles $\left({ }^{\circ}\right)$

\begin{tabular}{llll}
\hline $\mathrm{S} 1-\mathrm{C} 8$ & $1.640(3)$ & $\mathrm{C} 1-\mathrm{C} 7$ & $1.504(4)$ \\
$01-\mathrm{C} 10$ & $1.386(5)$ & $\mathrm{C} 2-\mathrm{C} 3$ & $1.377(4)$ \\
$01-\mathrm{C} 11$ & $1.429(4)$ & $\mathrm{C} 3-\mathrm{C} 4$ & $1.370(7)$ \\
$\mathrm{N} 1-\mathrm{C} 8$ & $1.351(4)$ & $\mathrm{C} 4-\mathrm{C} 5$ & $1.372(7)$ \\
$\mathrm{N} 1-\mathrm{C} 9$ & $1.475(4)$ & $\mathrm{C} 5-\mathrm{C} 6$ & $1.364(6)$ \\
$\mathrm{N} 1-\mathrm{C} 12$ & $1.431(4)$ & $\mathrm{C} 7-\mathrm{C} 8$ & $1.521(4)$ \\
$\mathrm{C} 1-\mathrm{C} 2$ & $1.387(4)$ & $\mathrm{C} 9-\mathrm{C} 10$ & $1.519(5)$ \\
$\mathrm{C} 1-\mathrm{C} 6$ & $1.387(5)$ & $\mathrm{C} 11-\mathrm{C} 12$ & $1.525(4)$ \\
$\mathrm{C} 10-\mathrm{O} 1-\mathrm{C} 11$ & $110.2(2)$ & $\mathrm{C} 4-\mathrm{C} 5-\mathrm{C} 6$ & $120.8(5)$ \\
$\mathrm{C} 8-\mathrm{N} 1-\mathrm{C} 9$ & $122.9(2)$ & $\mathrm{C} 1-\mathrm{C} 6-\mathrm{C} 5$ & $120.8(4)$ \\
$\mathrm{C} 8-\mathrm{N} 1-\mathrm{C} 12$ & $125.5(2)$ & $\mathrm{C} 1-\mathrm{C} 7-\mathrm{C} 8$ & $114.8(2)$ \\
$\mathrm{C} 9-\mathrm{N} 1-\mathrm{C} 12$ & $111.6(2)$ & $\mathrm{S} 1-\mathrm{C} 8-\mathrm{N} 1$ & $123.6(2)$ \\
$\mathrm{C} 2-\mathrm{C} 1-\mathrm{C} 6$ & $117.9(3)$ & $\mathrm{S} 1-\mathrm{C} 8-\mathrm{C} 7$ & $119.0(2)$ \\
$\mathrm{C} 2-\mathrm{C} 1-\mathrm{C} 7$ & $123.5(3)$ & $\mathrm{N} 1-\mathrm{C} 8-\mathrm{C} 7$ & $117.3(2)$ \\
$\mathrm{C} 6-\mathrm{C} 1-\mathrm{C} 7$ & $118.7(3)$ & $\mathrm{N} 1-\mathrm{C} 9-\mathrm{C} 10$ & $109.7(2)$ \\
$\mathrm{C} 1-\mathrm{C} 2-\mathrm{C} 3$ & $120.9(3)$ & $\mathrm{O} 1-\mathrm{C} 10-\mathrm{C} 9$ & $112.5(3)$ \\
$\mathrm{C} 2-\mathrm{C} 3-\mathrm{C} 4$ & $120.1(4)$ & $\mathrm{O} 1-\mathrm{C} 11-\mathrm{C} 12$ & $111.8(2)$ \\
$\mathrm{C} 3-\mathrm{C} 4-\mathrm{C} 5$ & $119.5(4)$ & $\mathrm{N} 1-\mathrm{C} 12-\mathrm{C} 11$ & $110.3(2)$ \\
\hline
\end{tabular}

Table 4 Hydrogen-bond geometry $\left(\AA{ }^{\circ}{ }^{\circ}\right)$

$\begin{array}{lllll}\text { C7--H7A..OO1 } & & \\ \text { C9--H9A..S1 } & 0.97 & 2.44 & 3.394(5) & 168 . \\ & 0.97 & 2.56 & 3.063(4) & 112 .\end{array}$

Symmetry operators: $(i)-1+x, y,-1+z$.

2. K. A. Petrov and L. N. Andreev, Russ. Chem. Rev., 1969, $38,21$.

3. T. Hoeg-Jensen, C. E. Olsen, and A. Holm, J. Org. Chem., 1994, 59, 1257.

4. L. J. Herbert Haller, and Wm. F. Barthel, U. S. Pat. 2,358,925, Sept. (1944); C. L. Leresque, U. S. Pat. 2,560,296, July 10 (1951).

5. Kureha Chemical Industry Co. Ltd. Jpn. Kokai Tokkyo Koho 8112 315, Feb 6 (1981).

6. Molecular Structure Corporation (1997). TEXSAN for Windows (Version 1.03) and Single Crystal Structure Analysis Software (Version 1.03). MSC, 3200 Research Forest Drive, The Woodlands, TX 77381, USA.

7. D. Cremer and J. A. Pople, J. Am. Chem. Soc., 1975, 97, 1354. 